\title{
Causes and timing of death in critically ill COVID-19 patients
}

\author{
Damien Contou* (i), Radj Cally, Florence Sarfati, Paul Desaint, Megan Fraissé and Gaëtan Plantefève
}

Mortality rate of critically ill COVID-19 patients is high, especially in those requiring invasive mechanical ventilation. However, the causes and the timing of death of patients admitted to the ICU for SARS-CoV-2 pneumonia have been poorly reported $[1,2]$. Whether patients mainly die from refractory respiratory failure directly due to SARS-CoV-2 pneumonia or from sepsis as reported in non-COVID-19 ARDS patients [3] is unknown. Moreover, the increased risk of pulmonary embolism extensively described among COVID-19 patients together with the SARS-CoV-2-associated myocardial injuries [4] may expose critically ill COVID-19 patients to death from a cardiac origin [5]. Additionally, the increased intensity of thromboprophylaxis commonly used to prevent thrombotic events might also promote fatal hemorrhagic events.

We therefore aimed to describe the main causes of death among critically ill COVID-19 patients admitted to our ICU, as well as to report the timing of each cause of death.

We retrospectively reviewed all deaths occurring in adult COVID-19 patients (RT-PCR positive for SARSCoV-2) admitted to our ICU between March 6th, 2020 and January 18th, 2021 for acute respiratory failure related to SARS-CoV-2 pneumonia.

Causes of death were categorized in four subgroups: (1) refractory respiratory failure, (2) shock with multiorgan failure, (3) cardiac death including proven pulmonary embolism (proximal thrombus on CT-pulmonary angiography with acute cor pulmonale on echocardiography and vasopressor requirement) and unexpected cardiac

*Correspondence: damien.contou@ch-argenteuil.fr Service de Réanimation Polyvalente, Centre Hospitalier Victor Dupouy, 69, rue du Lieutenant-Colonel Prud'hon, 95100 Argenteuil, France arrest (neither prior oxygen desaturation nor circulatory failure) and (4) neurological death (ischemic/hemorrhagic stroke with brain herniation).

After exclusion of COVID-19 patients still hospitalized, 152 patients were analyzed. Among them, 73 (48\%, 95\% confidence interval $40-56 \%$ ) died with a median delay of 14 [9-23] days after ICU admission. Characteristics of the patients dying in the ICU are detailed in the Table 1.

Distribution of the main causes of death (panel a) and timing of each cause of death (panel b) are detailed in the Fig. 1. The leading cause of death was refractory respiratory failure which accounted for $45 \%$ of ICU deaths. Cardiac deaths (all occurring in intubated patients) included 4 pulmonary embolisms (intravenous thrombolysis, $n=3$ ) and 9 unexpected cardiac arrests (asystole, $n=7$; pulseless electrical activity, $n=2$ ). Neurological deaths included hemorrhagic $(n=4)$ and ischemic $(n=1)$ strokes. Overall, $10(14 \%)$ and $6(8 \%)$ patients directly died from a thrombotic or hemorrhagic event, respectively.

None of the patients dying from shock with multiorgan failure or from cardiac death died after a withholding (all the patients with unexpected cardiac arrest underwent cardiopulmonary resuscitation) or withdrawal procedure while all patients dying from a neurological cause died after a withdrawal procedure. Among patients dying from refractory respiratory failure, 22 (66\%) and 4 died after a withholding (tracheal intubation, $n=2$; extracorporeal membrane oxygenation, $n=19$; renal replacement therapy, $n=1$ ) or withdrawal procedure, respectively.

As opposed to non-COVID19 ARDS patients [3, 6], we herein report that refractory respiratory failure was the leading cause of death among COVID-19 ARDS patients, consistent with a previous report [2]. Deaths

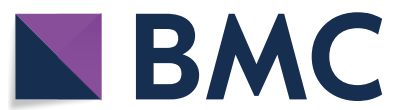

(c) The Author(s) 2021. Open Access This article is licensed under a Creative Commons Attribution 4.0 International License, which permits use, sharing, adaptation, distribution and reproduction in any medium or format, as long as you give appropriate credit to the original author(s) and the source, provide a link to the Creative Commons licence, and indicate if changes were made. The images or other third party material in this article are included in the article's Creative Commons licence, unless indicated otherwise in a credit line to the material. If material is not included in the article's Creative Commons licence and your intended use is not permitted by statutory regulation or exceeds the permitted use, you will need to obtain permission directly from the copyright holder. To view a copy of this licence, visit http://creativecommons.org/licenses/by/4.0/. The Creative Commons Public Domain Dedication waiver (http://creativeco mmons.org/publicdomain/zero/1.0/) applies to the data made available in this article, unless otherwise stated in a credit line to the data. 
Table 1 Characteristics of 73 critically ill COVID-19 patients dying during ICU stay

\begin{tabular}{|c|c|}
\hline & $\begin{array}{l}\text { COVID-19 } \\
\text { patients dying } \\
\text { in ICU } \\
N=73\end{array}$ \\
\hline \multicolumn{2}{|l|}{ Patient's characteristics and ICU scores } \\
\hline Male sex & $56(77)$ \\
\hline Age, years & $68[62-73]$ \\
\hline SAPS II upon ICU admission & $37[29-45]$ \\
\hline SOFA upon ICU admission & $4[3-8]$ \\
\hline \multicolumn{2}{|l|}{ Main comorbidities } \\
\hline Arterial hypertension & $52(71)$ \\
\hline Diabetes mellitus & $35(48)$ \\
\hline Ischemic cardiopathy & $10(14)$ \\
\hline Chronic respiratory disease & $18(25)$ \\
\hline Immunocompromised status & $18(25)$ \\
\hline \multicolumn{2}{|l|}{ Main delays } \\
\hline Days between disease onset and ICU admission & $8[6-11]$ \\
\hline$>7$ days between disease onset and ICU admission & $51(70)$ \\
\hline \multicolumn{2}{|l|}{ Biological data upon ICU admission } \\
\hline D-dimers (ng/mL) & $2505[1555-5877]$ \\
\hline Fibrinogen ( $g / L)$ & $7.3[5.6-8.5]$ \\
\hline \multicolumn{2}{|l|}{ Treatment administered upon ICU admission } \\
\hline Glucocorticoids & $35(48)$ \\
\hline Intermediate or full-dose thromboprophylaxis & $53(73)$ \\
\hline Antibiotic therapy for bacterial co-infection at ICU admission & $20(27)$ \\
\hline Antiviral drugs (lopinavir-ritonavir or remdesivir) & $0(0)$ \\
\hline Tocilizumab & $0(0)$ \\
\hline \multicolumn{2}{|l|}{ Outcome in the ICU } \\
\hline Invasive mechanical ventilation (IMV) & $71(97)$ \\
\hline Days between ICU admission and IMV & $2[1-4]$ \\
\hline Days between disease onset and IMV & $11[8-14]$ \\
\hline Ventilator associated pneumonia & $47(64)$ \\
\hline Prone positioning & $62(85)$ \\
\hline Extra corporal membrane oxygenation & $3(4)$ \\
\hline Tracheostomy & $2(3)$ \\
\hline Renal replacement therapy & $26(36)$ \\
\hline Vasopressor support & $64(88)$ \\
\hline Thrombotic events during ICU stay & $26(36)$ \\
\hline Hemorrhagic events during ICU stay & $17(23)$ \\
\hline Delay between ICU admission and death, days & 14 [9-23] \\
\hline
\end{tabular}

Continuous variables are reported as medians [quartile 1-quartile 3] and categorical variables are reported as numbers (percentages)

ACE/ARB Angiotensin-Converting Enzyme Inhibitors/Angiotensin Receptor Blockers, ICU Intensive Care Unit, IMV Invasive Mechanical Ventilation, SAPS2 Simplified Acute Physiology Score, SOFA Sequential Organ Failure Assessment

by refractory respiratory failure occurred late in the ICU course, potentially as a result of pulmonary fibrosis induced by SARS-CoV-2 and prolonged mechanical ventilation, making futile the use of extracorporeal membrane oxygenation support.

Noteworthy, cardiac deaths related to pulmonary embolism or unexpected cardiac arrest accounted for
$18 \%$ of the deaths and occurred early in the ICU course. Similarly, a large multicenter study reported that up to $14 \%$ of the critically ill COVID-19 patients experienced cardiac arrest, mainly due to pulseless electrical activity and asystole, as a possible manifestation of fulminant myocarditis or proximal pulmonary embolism $[2,5]$. 


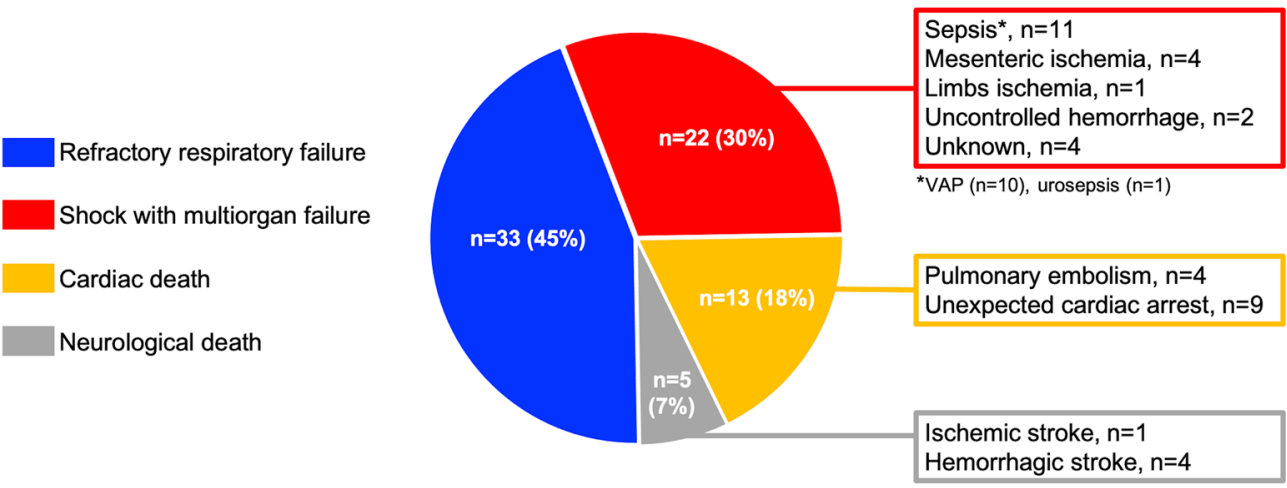

a

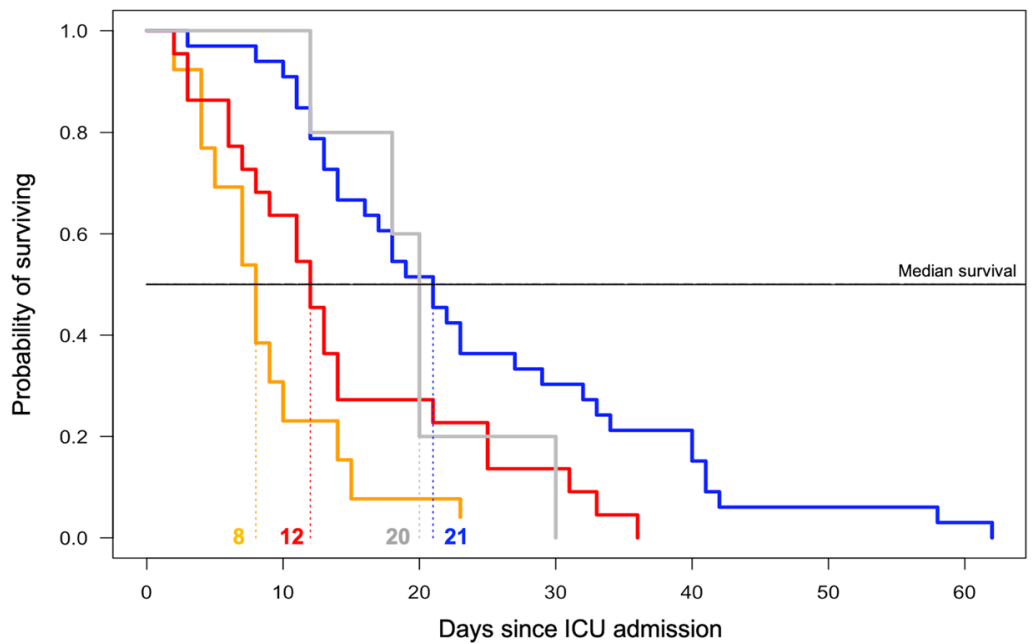

\section{1 [13-33] days}

12 [7-19] days

8 [5-10] days

20 [18-20] days

Timing of death

median [q1-q3]

Timing of death

Overall median delay 14 [9-23] days

Fig. 1 a Distribution of each cause of death among 73 critically ill COVID-19 patients dying during the ICU stay (VAP ventilator-associated pneumonia). b Kaplan-Meier survival estimates following ICU admission and median delay [quartile 1-quartile 3] (in days) between ICU admission and death according to each cause of death. In both panels, deaths from refractory respiratory failure, shock with multi-organ failure, cardiac and neurologic causes figure in blue, red, orange and grey, respectively

Even if our study suffers from several limitations including its monocenter retrospective design, the limited number of patients and the lack of control with non-COVID-19 patients, it provides an informative picture of the main causes of death of critically ill COVID-19 patients.

\section{Acknowledgements}

We warmly acknowledge Dr. Jo-Anna Tirolien, Dr. Olivia Picq, Dr. Olivier Pajot, Dr. Hervé Mentec and all the residents who cared of the patients.

\section{Authors' contributions}

$\mathrm{DC}, \mathrm{GP}$ and $\mathrm{RC}$ are responsible for the conception and design. All the authors took care of the patients. DC, MF and RC are responsible for data acquisition. All the authors were responsible for analysis and interpretation of data. All authors read, critically reviewed and approved the final manuscript. DC takes responsibility for the paper as a whole.

\section{Funding}

No funding.

\section{Availability of data and materials}

The dataset used and analyzed for the current study is available from the corresponding author on reasonable request. 


\section{Ethics approval and consent to participate}

This study was conducted in accordance with the amended Declaration of Helsinki and was approved by the Institutional Review Board (CE 2021-008) of the French Intensive Care Society.

\section{Consent for publication}

Not applicable.

\section{Competing interests}

The authors declare that they have no competing interests.

Received: 26 January 2021 Accepted: 8 February 2021

Published online: 23 February 2021

\section{References}

1. Vincent J-L, Taccone FS. Understanding pathways to death in patients with COVID-19. Lancet Respir Med. 2020;8:430-2.

2. Ruan Q, Yang K, Wang W, Jiang L, Song J. Clinical predictors of mortality due to COVID-19 based on an analysis of data of 150 patients from Wuhan, China. Intensive Care Med. 2020;46:846-8.
3. Stapleton RD, Wang BM, Hudson LD, Rubenfeld GD, Caldwell ES, Steinberg KP. Causes and timing of death in patients with ARDS. Chest. 2005:128:525-32.

4. Guo T, Fan Y, Chen M, Wu X, Zhang L, He T, et al. Cardiovascular implications of fatal outcomes of patients with coronavirus disease 2019 (COVID19). JAMA Cardiol. 2020;5:751-3.

5. Hayek SS, Brenner SK, Azam TU, Shadid HR, Anderson E, Berlin H, et al. In-hospital cardiac arrest in critically ill patients with covid-19: multicenter cohort study. BMJ. 2020:371:m3513.

6. Ketcham SW, Sedhai YR, Miller HC, Bolig TC, Ludwig A, Co I, et al. Causes and characteristics of death in patients with acute hypoxemic respiratory failure and acute respiratory distress syndrome: a retrospective cohort study. Crit Care. 2020;24:391.

\section{Publisher's Note}

Springer Nature remains neutral with regard to jurisdictional claims in published maps and institutional affiliations.
Ready to submit your research? Choose BMC and benefit from:

- fast, convenient online submission

- thorough peer review by experienced researchers in your field

- rapid publication on acceptance

- support for research data, including large and complex data types

- gold Open Access which fosters wider collaboration and increased citations

- maximum visibility for your research: over 100M website views per year

At BMC, research is always in progress.

Learn more biomedcentral.com/submissions 